\title{
Mycoplasma spp. in captive snakes (Boa constrictor and Bothrops atrox) from Brazil
}

\author{
Barbara Souza Neil Magalhães ${ }^{1}$ Leandro dos Santos Machado ${ }^{1}$ Arthur de Almeida Figueira ${ }^{1}$ \\ Thomas Salles Dias $^{1^{*}}$ (D) Thiago de Almeida Feijó ${ }^{3}$ Maria Lucia Barreto ${ }^{2}$ Giulia de Almeida Tuffanelli ${ }^{1}$ \\ Nathalie Costa da Cunha ${ }^{1}$ Elmiro Rosendo do Nascimento ${ }^{1}$ \\ Virginia Léo de Almeida Pereira ${ }^{1}$ Nádia Regina Pereira Almosny ${ }^{1}$
}

${ }^{1}$ Faculdade de Veterinária, Universidade Federal Fluminense (UFF), 24230-340, Niterói, RJ, Brasil. E-mail: thomassalles@id.uff.br. ${ }^{*}$ Corresponding author.

${ }^{2}$ Instituto de Biologia, Universidade Federal Fluminense (UFF), Niterói, RJ, Brasil.

${ }^{3}$ Fundação Jardim Zoológico da Cidade do Rio de Janeiro, Rio de Janeiro, RJ, Brasil.

ABSTRACT: Although rare, mycoplasmas are included among the causes of respiratory diseases in reptiles and, in the order Squamata, three reports of these microorganisms causing diseases in pythons have already been reported. This study aimed to evaluate the occurrence of Mycoplasma species in captive snakes. A total of 26 snakes of the families Pythonidae (13), Boidae (7), Viperidae (5) and Colubridae (1) from RioZoo, Brazil, were evaluated. Animals were examined to determine clinical signs consistent with any infectious disease. Tracheal swab samples from snakes were collected in Frey medium and analyzed for the presence of Mycoplasma spp.by isolation and a genus-specific PCR. DNA sequencing analyses of six positive samples by PCR were carried out to identify the species. Using isolation 19.23\% (5/26) was positive, while 65.38\% (17/26) of the animals were positive by PCR. Based on the analyses of the six sequences obtained, there was similarity with a Mycoplasma spp. previously described in a phyton and, M. agassizii and M. testudineum reported in chelonians. This is the first report of Mycoplasma spp. in animals of the families Boidae and Viperidae. Mycoplasma spp. were detected in snakes with and without clinical signs. The mycoplasmas reported resented identity (range, 95\% to 100\%) to others already described in reptiles. There was no relationship between the presence of Mycoplasma spp. and clinical signs.

Key words: Mycoplasmosis, Mollicutes, Order Squamata, Boidae, Viperidae.

Mycoplasma spp. em cobras de cativeiro (Boa constrictor e Bothrops atrox) do Brasil

RESUMO: Embora raros, os micoplasmas estão incluidos entre as causas de doenças respiratórias em répteis e, na ordem Squamata, já foram realizados três relatos destes microrganismos causando doença em pítons. Este estudo teve como objetivo avaliar a ocorrência de espécies de Mycoplasma em serpentes em cativeiro. Foram avaliadas 26 serpentes das familias Pythonidae (13), Boidae (7), Viperidae (5) e Colubridae (1) do RioZoo, Brasil. Os animais foram examinados para determinar sinais clínicos consistentes com qualquer doença infecciosa. Amostras de swab traqueal de cobras foram coletadas em meio Frey e analisadas por isolamento microbiológico e pela técnica da PCR para identificar Mycoplasma spp. As amostras positivas para o gênero Mycoplasma spp. foram submetidas ao sequenciamento genético para identificação das espécies. No isolamento, 19,23\% (5/26) foram positivos, enquanto 65,38\% (17/26) dos animais foram positivos por PCR. Com base nas análises das seis sequências obtidas, houve similaridade com o Mycoplasma spp. descrito anteriormente em um piton e M. agassizii e M. testudineum encontrados em quelônios. Este é o primeiro relato de Mycoplasma spp. em animais das famílias Boidae e Viperidae. Mycoplasma spp. foi detectado em serpentes com e sem sinais clínicos. Os micoplasmas encontrados apresentaram semelhança genética com outros já descritos em répteis. Não houve relação entre a presença de Mycoplasma spp. e sinais clínicos.

Palavras-chave: Micoplasmose, Molicutes, Ordem Squamata, Boidae, Viperidae.

\section{INTRODUCTION}

In reptiles, many infectious agents, including viruses, bacteria, fungi, and parasites, have been linked to morbidity and mortality in wild and captive populations. Respiratory tract are among the major affected system in these animals, and most of the agents isolated from sick reptiles are Gram- negative bacteria, including Pseudomonas spp., Aeromonas spp., Salmonella spp., Proteus spp., and Klebsiella spp. (SCHUMACHER, 2006).

Although rare, mycoplasmas are included among the causes of respiratory diseases in reptiles; then tortoises present mycoplasmosis, with nasal and ocular exudate, palpebral edema, rhinitis, tracheitis, pneumonia and stomatitis as major clinical 
manifestations; although, cases of animals with subclinical manifestations or even asymptomatic are also reported. There are two species of Mycoplasma known as pathogenic and causative agents of upper respiratory tract infections in chelonians, $M$. agassizii and M. testudineum (BROWN et al., 1994; BROWN et al., 2004; JACOBSON et al., 2012; JACOBSON et al., 2014; OSSIBOFF et al., 2015; SEIMON et al., 2017). In crocodilians, mycoplasma has been reported as a cause of pneumonia, tracheitis and polyarthritis (KIRCHHOFF et al., 1997; DRIGGERS et al., 2000).

Reports of mycoplasmas in Serpentes (Ophidia) are rare and three cases were reported in pythons (PENNER et al., 1997; SCHMIDT et al., 2013; MARSHANG et al., 2016). In two cases the detected bacteria were classified as Mycoplasma spp. (PENNER et al., 1997; MARSHANG et al., 2016) and in one case, the detected sequence was closely related to corresponding sequences from $M$. caviae and M. fermentans (SCHMIDT et al., 2013). In other squamates, $M$. iguanae was described as possible causative agent of spinal cord degeneration in two green iguanas (Iguana iguana) (BROWN et al., 2006), but a subsequent study was not able to induce disease by inoculation of $M$. iguanae and also report $M$. insons sp. nova in both inoculated and uninoculated iguanas. Therefore, M. iguanae was considered unlikely to be an agent of acute disease in iguanas and $M$. insons was considered as normal flora in the respiratory tract of iguanas (BROWN et al., 2007).

Due to the few reports of Mycoplasma in snakes, its relationship with clinical signs is poorly studied and the absence of Koch's postulates raise the question about the mycoplasmas role as causing of disease in these animals. The aim of this study was to evaluate the occurrence of Mycoplasma species in captive snakes.

\section{MATERIALS AND METHODS}

This project was submitted and approved under number 1017 by the Ethics Committee on Use Animal Use (CEUA) from the Fluminense Federal University (UFF), by the Biodiversity Authorization and Information System (SISBIO-ICMBio) under no. 59538-1 and was also registered at the National System for the Management of Genetic Resources and Associated Traditional Knowledge (SISGEN), no. A4E34FC.

The study included 26 snakes from Rio de Janeiro Zoo, located in the State of Rio de Janeiro, Brazil. The snakes belong to ten different species from the families Pythonidae $(n=13)$, Boidae $(n=7)$, Viperidae $(\mathrm{n}=5)$, and Colubridae $(\mathrm{n}=1)$. Viperidae and colubridae snakes were housed in individual cages, Pythons were kept in 2 groups according to species (group $1=9$ Burmese pythons and group $2=4$ Ball pythons) and all boids were housed together in the same enclosure. The groups /animals housed individually had no contact with one another or with other animals. Animals were examined to determine clinical signs consistent with any infectious disease. Thereafter, tracheal swabs were collected and packaged in 1,8 $\mathrm{mL}$ of modified Frey medium (NASCIMENTO \& PEREIRA, 2009), cooled and forwarded immediately to the Molecular Epidemiology Laboratory of Faculty of Veterinary for analysis by isolation and polymerase chain reaction (PCR) on the same day.

\section{Isolation of Mycoplasma spp.}

From each animal one aliquot of $0.2 \mathrm{~mL}$ of the collected sample was inoculated in $1.8 \mathrm{~mL}$ of liquid Frey medium. Afterwards, serial dilutions up to $10^{-5}$ were carried out and the dilutions $10^{-3}$ and $10^{-5}$ were inoculated onto plates containing modified solid Frey medium. All samples were incubated at 37 ${ }^{\circ} \mathrm{C}$ under microaerophilic conditions and observed on a daily basis for 21 days, at $100 \mathrm{X}$ magnification using stereoscopic microscope. The colonies presenting the characteristics of mycoplasmas in the solid medium were examined using Dienes' stain and a digitonin sensitivity test to confirm that they were Mycoplasma spp.

\section{$D N A$ extraction and $P C R$}

Aliquots of $500 \mu \mathrm{L}$ from tracheal swab samples soaked in modified Frey medium, and the positive cultures from each animal were submitted to DNA extraction using the phenol-chloroform method adapted (Sambrook \& Russell, 2006). Subsequently, the samples were submitted to a genus-specific PCR for mycoplasma detection (UPHOFF \& DREXLER, 2002). The amplification reaction contained: ultrapure water Milli-Q, 1X PCR buffer, $2.0 \mathrm{mM}$ of $\mathrm{MgCl}_{2}, 0.8$ $\mathrm{mM}$ of dNTP mix, $0.6 \mu \mathrm{M}$ of each primer specific for Mycoplasma spp. (Table 1), 1U of Taq Polymerase $(5 \mathrm{U} / \mu \mathrm{L})$ and $5 \mu \mathrm{L}$ of extracted DNA with a final volume of $25 \mu \mathrm{L}$. Mycoplasma gallisepticum (MGR-ATCC 19619) was used as positive control and ultrapure water Milli-Q as negative control of the reaction.

Reactions were performed in PTC$100^{\circledR}$ thermocycler (Bio-Rad Laboratories, Ltda., Hertfordshire, England) using the following conditions: $95{ }^{\circ} \mathrm{C}$ for 5 minutes, followed by 30 cycles of denaturation at $94{ }^{\circ} \mathrm{C}$ for 30 seconds, 
Table 1 - Primers, expected amplicon size for detection of Mycoplasma spp.

\begin{tabular}{lcc}
\hline Primer & Nucleotide sequence & Amplicon \\
\hline MsppF1 & CGCCTGAGTAGTACGTTCGC & \\
\hline MsppF2 & CGCCTGAGTAGTACGTACGC & \\
\hline MsppF3 & TGCCTGAGTAGTACATTCGC & Uphoff \& Drexler, 2002 \\
MsppF4 & TGCCTGGGTAGTACATTCGC & 500pb \\
\hline MsppF5 & CGCCTGGGTAGTACATTCGC & \\
\hline MsppF6 & CGCCTGAGTAGTATGCTCGC & \\
\hline MsppR1 & GCGGTGTGTACAAGACCCGA & \\
\hline MsppR2 & GCGGTGTGTACAAAACCCGA & \\
\hline
\end{tabular}

annealing at $55{ }^{\circ} \mathrm{C}$ for 30 seconds and extension at $72{ }^{\circ} \mathrm{C}$ for 1 minute and 30 seconds, and a final cycle of $72{ }^{\circ} \mathrm{C}$ for 7 minutes. The amplicons obtained in the PCR were separated in agarose gel at $1.5 \%$, immersed in Tris-Borate-EDTA (TBE) buffer, and submitted to an electrophoretic run of 94 Volts for 40 minutes. After the electrophoretic run, the gel was stained in ethidium bromide and the amplicons were visualized under ultraviolet light in a transilluminator. For samples with mycoplasma-positive result a $500 \mathrm{bp}$ amplicon was expected.

\section{Purification, sequencing and analysis}

Samples positive for Mycoplasma spp. were submitted to DNA sequencing to identify the species. The 500 bp amplicons were purified by Illustra GFX PCR DNA and Gel Band Purification Kit (GE Healthcare). Purified products were sent to the Sequencing Platform subunit RPT01A of Oswaldo Cruz Institute, where they were sequenced using automatic sequencer ABI3730 (Applied Biosystems $^{\circledR}$, Foster City, California, USA). Sequences generated were trimmed in Bioedit, deposited in the GenBank ${ }^{\circledR}$ database (Accession numbers MK918637 to MK918642). Phylogeny was inferred by using the Maximum Likelihood method and Kimura 2-parameter model (KIMURA, 1980). The bootstrap consensus tree inferred from 1000 replicates was used to infer the phylogeny of the taxa analyzed, and branches corresponding to partitions reproduced in less than $50 \%$ bootstrap replicates were collapsed. Percentage of replicate trees in which the associated taxa clustered together in the bootstrap test (1000 replicates) are shown next to the branches. Initial trees for the heuristic search were obtained automatically by applying Neighbor-Join and BioNJ algorithms to a matrix of pairwise distances estimated using the Maximum Composite Likelihood (MCL) approach, and then selecting the topology with superior log likelihood value. This analysis involved 18 nucleotide sequences. Codon positions included were $1 \mathrm{st}+2 \mathrm{nd}+3 \mathrm{rd}+$ Noncoding. All positions containing gaps and missing data were eliminated (complete deletion option). There was a total of 347 positions in the final dataset. Phylogenetic analyses were conducted in MEGA X (KUMAR et al., 2018).

\section{Statistical analysis}

Statistical analysis was performed using the program BioEstat 5.0. Difference between the presence of Mycoplasma spp. and presence or absence of clinical signs were examined for significance at a 0.05 level using Fisher's exact test.

\section{RESULTS AND DISCUSSION}

By isolation, 19.23\% (5/26) were positive for Mycoplasma spp. and the identity of the isolates was confirmed by Dienes and digitonin tests and PCR. Of the 26 snakes tested, PCR products with a similar size to those expected for Mycoplasma spp. were obtained from $65.4 \%$ (17/26). Based on DNA sequencing, six sequences $(6 / 17)$ had good quality and the other eleven sequences obtained had low quality and were discarded for further analysis (Table 2). After trimming in Bioedit software the length of the six sequences ranged from $358 \mathrm{pb}$ to $438 \mathrm{pb}$. Only three animals (Python regius, Boa constrictor constrictor and Bothrops atrox) presented clinical signs, such as stomatitis, anorexia, and weight loss, and were positive for Mycoplasma spp. in PCR and isolation. When comparing animals regarding the presence of mycoplasma and clinical signs no statistical difference was observed by Fisher exact test $(\mathrm{p}=0.9981)$.

The sequences (GenBank access numbers 
Table 2 - Snakes tested for Mycoplasma spp. grouped by family, species and identification number of each the animal, and presence/absence of Mycoplasma by isolation and PCR, and accession number of the sequences deposited in GenBank database.

\begin{tabular}{|c|c|c|c|c|c|}
\hline \multirow[t]{2}{*}{ Family } & \multirow[t]{2}{*}{ Species } & \multirow[t]{2}{*}{ Identification of the animal } & \multicolumn{2}{|c|}{ Results for Mycoplasma } & \multirow[t]{2}{*}{ Genbank ID } \\
\hline & & & Isolation & PCR & \\
\hline \multirow[t]{13}{*}{ Pythonidae } & Burmese python (Python bivittatus) & $\mathrm{S} 1$ & - & + & MK918638 \\
\hline & Burmese python (Python bivittatus) & $\mathrm{S} 2$ & - & + & MK918637 \\
\hline & Burmese python (Python bivittatus) & S3 & - & + & MK918639 \\
\hline & Burmese python (Python bivittatus) & $\mathrm{S} 4$ & - & + & \\
\hline & Burmese python (Python bivittatus) & S5 & - & + & \\
\hline & Burmese python (Python bivittatus) & S6 & - & + & MK918641 \\
\hline & Burmese python (Python bivittatus) & S7 & - & + & MK918640 \\
\hline & Burmese python (Python bivittatus) & S8 & - & + & \\
\hline & Burmese python (Python bivittatus) & S9 & + & + & \\
\hline & Ball python (Python regius) & $\mathrm{S} 13$ & + & + & \\
\hline & Ball python (Python regius) & S15 & - & - & \\
\hline & Ball python (Python regius) & $\mathrm{S} 17$ & - & + & \\
\hline & Ball python (Python regius) & $\mathrm{S} 16$ & - & + & \\
\hline \multirow[t]{7}{*}{ Boidae } & Boa constrictor snake (Boa constrictor) & $\mathrm{S} 11$ & + & + & \\
\hline & Boa constrictor snake (Boa constrictor) & $\mathrm{S} 12$ & + & + & \\
\hline & Boa constrictor snake (Boa constrictor) & $\mathrm{S} 18$ & - & + & MK918642 \\
\hline & Boa constrictor snake (Boa constrictor) & $\mathrm{S} 10$ & - & + & \\
\hline & Amazon tree boa (Corallus hortulanus) & $\mathrm{S} 24$ & - & - & \\
\hline & Rainbow boa (Epicrates choenchria) & $\mathrm{S} 25$ & - & - & \\
\hline & Green Anaconda (Eunectes murinus) & S19 & - & - & \\
\hline \multirow[t]{5}{*}{ Viperidae } & Common lancehead (Bothrops atrox) & $\mathrm{S} 14$ & + & + & \\
\hline & $\begin{array}{c}\text { Neuwied's lancehead (Bothropoides } \\
\text { neuwiedi) }\end{array}$ & $\mathrm{S} 22$ & - & - & \\
\hline & $\begin{array}{l}\text { South American rattlesnake (Crotalus } \\
\qquad \text { durissus) }\end{array}$ & $\mathrm{S} 20$ & - & - & \\
\hline & $\begin{array}{l}\text { South American rattlesnake (Crotalus } \\
\qquad \text { durissus) }\end{array}$ & $\mathrm{S} 21$ & - & - & \\
\hline & $\begin{array}{l}\text { South American rattlesnake (Crotalus } \\
\qquad \text { durissus) }\end{array}$ & $\mathrm{S} 23$ & - & - & \\
\hline Colubridae & $\begin{array}{c}\text { Western rat snake (Pantherophis } \\
\text { obsoletus) }\end{array}$ & $\mathrm{S} 26$ & - & - & \\
\hline Total & & 26 & 5 & 17 & \\
\hline
\end{tabular}

MK918637 to MK918642), presented 100\% identity with a Mycoplasma sp. sequence (GenBank access numbers KU862617) described by MARSHANG et al., (2016) in a python with stomatitis. Also was detected a similarity with sequences from strains of $M$. agassizii (GenBank access numbers KY212528.1 to KY212536.1), and M. testudineum (GenBank access numbers FJ666138, NR 115220.1, NR 044767.1) reported in chelonians and M. iguanae (GenBank access number AY714305) in iguanas. Phylogenetic tree (Figure 1) demonstrated the relationship among mycoplasmas based on the sequenced portions of the 16S rRNA gene reported in this study and the sequences from the GenBank database.

This study is the first report of the isolation and characterization of Mycoplasma spp. from boids and viperidae snakes. In a study (SCHMIDT et al., 2013) with 80 snakes from Families Boidae and Pythonidae, Mycoplasma spp. was detected in two pythons, one with and the other without respiratory clinical signs; although, both presented pneumonia 


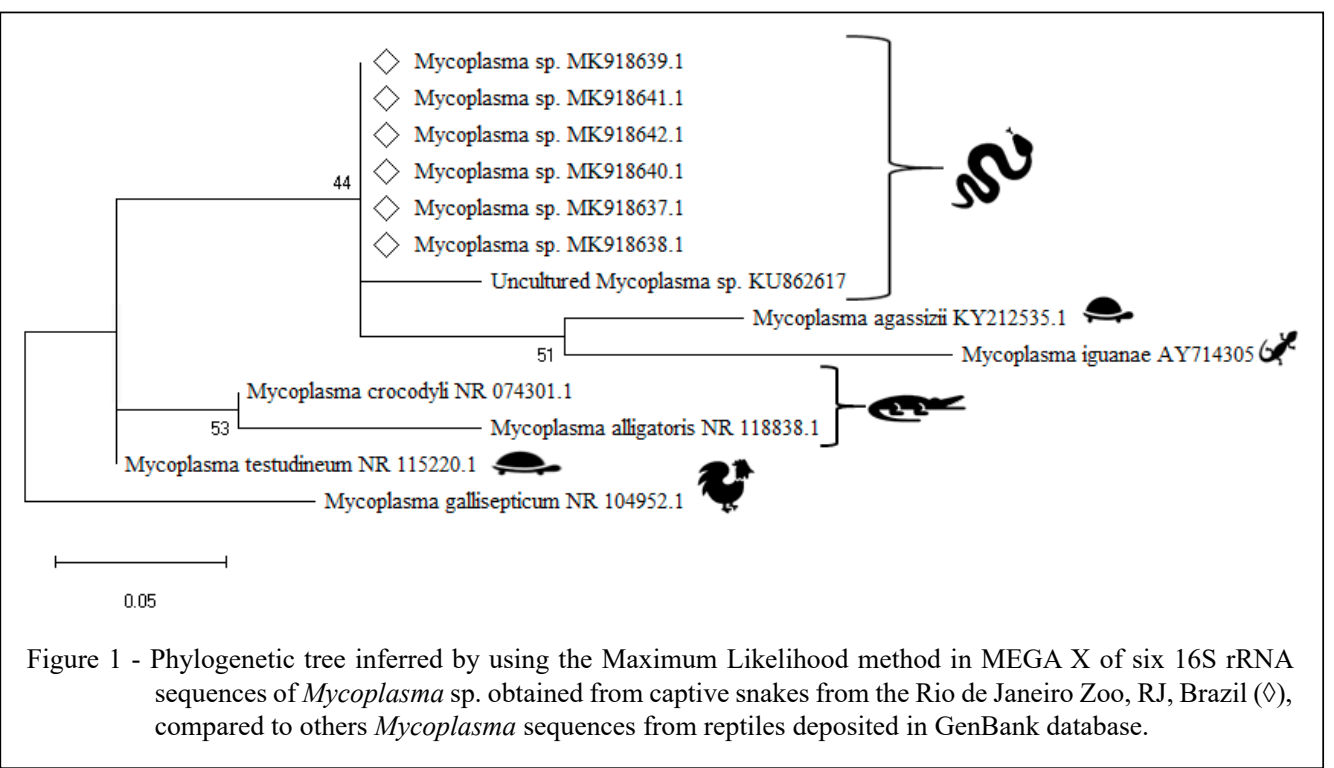

at necropsy. MARSCHANG et al., (2016) detected Mycoplasma spp. in one carpet python (Morelia spilota), which presented mild purulent to purulentnecrotic stomatitis on postmortem examination. This animal was in good body condition and was negative for adenoviruses, snake arenaviruses, python nidoviruses, ferlaviruses, reoviruses and herpesviruses in the laboratory tests. Only symptomatic animals were tested for Mycoplasma spp. in MARSHANG et al., (2016) study, preventing a direct comparison with our study, which was possible to detect the agent in $53.84 \%(14 / 26)$ of the snakes without clinical signs.

Among 26 snakes four presented anorexia, three presented retention of skin shedding, and two animals presented stomatitis. Anorexia, stomatitis, and retention of skin shedding may be related to diverse causes such microorganism infections, traumas, inadequate nutrition, inappropriate environmental temperature, or humidity (FUNK, 2006; MEHLER, 2006). Stomatitis was also reported in previous relates of Mycoplasma spp. infection (MARSHANG et al., 2016; SCHMIDT et al., 2013; PENNER et al., 1997), which may indicate this as a clinical sign of Mycoplasma infection.

However, the high positivity rate for Mycoplasma spp. by PCR in asymptomatic snakes leads us to question if Mycoplasma spp. reported was the causative agent of the disease or an opportunist that multiplies in cases of association with other agents and/or immunosuppression. Various possible causes for respiratory signs and stomatitis have already been described, as inappropriate management, which may lead to stress and trauma (CZIRJÁK et al., 2015), bacteria (SCHMIDT et al., 2013), virus including herpesviruses (LOVSTAD et al., 2019), nidoviruses (STENGLEIN et al., 2014), and paramyxoviruses (STARCK et al., 2017). None of these agents were tested in this study; therefore, the possibility of coinfection or infections caused by other agents in the animals presenting clinical signs cannot be ruled out. Nonetheless, the presence of Mycoplasma spp. confirmed by PCR in the animals analyzed in this study is an interesting finding, since there is little information about infection by this agent in snakes.

The six sequences obtained presented similarity with mycoplasma described in chelonians of the order Testudines (BROWN et al., 1995; LECIS et al., 2011). This supports studies by PENNER et al., (1998) and MARSCHANG et al., (2016) which described the presence of Mycoplasma spp. in snakes similar to that reported in chelonians. Different from what was found in this study, SCHMIDT et al., (2013) reported mycoplasma in two pythons with sequences with $95 \%$ similarity with corresponding sequences from $M$. caviae and M. fermentans (access number FR869692.1), which are associated with infections in rodents and humans, respectively.

\section{CONCLUSION}

In conclusion, it was possible to detect Mycoplasma spp. in snakes with and without clinical signs in captivity at Rio de Janeiro Zoo. There was no relationship between the presence of 
Mycoplasma spp. and clinical signs. The mycoplasmas reported were $100 \%$ homologous with a Mycoplasma sp. sequence described in a python with stomatitis and genetically similar to $M$. agassizii and $M$. testudineum, pathogenic species found in chelonians. Considering this, more studies on the prevalence and agent-host relation regarding mycoplasmas in order Squamata are necessary.

\section{ACKNOWLEDGEMENTS}

This study was financed in part by the Coordenação de Aperfeiçoamento de Pessoal de Nível Superior - Brasil (CAPES) -Finance Code 001 and Fundação Carlos Chagas Filho de Amparo à Pesquisa do Estado do Rio de Janeiro.

\section{BIOETHICS AND BIOSSECURITY COMMITTEE APPROVAL}

This project was submitted and approved under number 1017 by the Ethics Committee on Use Animal Use (CEUA) from the Fluminense Federal University, and by the Biodiversity Authorization and Information System (SISBIO-ICMBio) under no. 59538-1.

\section{DECLARATION OF CONFLICTS OF INTERESTS}

The authors declare no conflict of interest. The founding sponsors had no role in the design of the study; in the collection, analyses, or interpretation of data; in the writing of the manuscript, and in the decision to publish the results.

\section{AUTHORS' CONTRIBUTIONS}

All authors contributed equally for the conception and writing of the manuscript. All authors critically revised the manuscript and approved of the final version.

\section{REFERENCES}

BROWN, D. R. et al. Taxonomic analysis of the Tortoise Mycoplasmas Mycoplasma agassizii and Mycoplasma testudinis by $16 \mathrm{~S}$ rRNA Gene Sequence Comparison. International Journal of Systematic Bacteriology, [S. 1.], v.45, n.2, p.348-350, 1995. Available from: <http://doi.org/10.1099/00207713-45-2-348>. Accessed: Jun. 15, 2020. doi: 10.1099/00207713-45-2-348.

BROWN, D. R. et al. Mycoplasma alligatoris sp. nov., from American alligators. International Journal of Systematic and Evolutionary Microbiology, [S. 1.], v.51, n.2, p.419-424, 2001. Available from: <http://doi.org/10.1099/00207713-51-2-419>. Accessed: Jun. 15, 2020. doi: 10.1099/00207713-51-2-419.

BROWN, D. R. et al. Mycoplasma testudineum sp. nov., from a desert tortoise (Gopherus agassizii) with upper respiratory tract disease. International Journal of Systematic and Evolutionary Microbiology, [S. l.], v. 54, n. 5, p. 1527-1529, 2004. Available from: <http://doi.org/10.1099/ijs.0.63072-0>. Accessed: June 15, 2020. doi: 10.1099/ijs.0.63072-0.

BROWN, D. R. et al. Mycoplasma iguanae sp. nov., from a green iguana (Iguana iguana) with vertebral disease. International
Journal of Systematic and Evolutionary Microbiology, [S. 1.], v.56, n.4, p.761-764, 2006. Available from: <http://doi.org/10.1099/ ijs.0.63852-0>. Accessed: Jun. 15, 2020. doi: 10.1099/ijs.0.63852-0.

BROWN, D. R. et al. Mycoplasmosis in green iguanas (Iguana iguana). Journal of Zoo and Wildlife Medicine, [S. 1.], v.38, n.2, p.348-351, 2007. Available from: <http://doi.org/10.1638/10427260(2007)038[0348:MIGIII]2.0.CO;2>. Accessed: Jun. 15, 2020. doi: 10.1638/1042-7260(2007)038[0348:MIGIII]2.0.CO;2.

BROWN, M. B. et al. Mycoplasma agassizii causes upper respiratory tract disease in the desert tortoise. Infection and Immunity, [S. 1.], v.62, n.10, p.4580-4586, 1994.

CZIRJÁK, G. Á. et al. Hemorrhagic stomatitis in a natural hybrid of Vipera ammodytes $\times$ Vipera berus due to inappropriate substrate in terrarium. Journal of Veterinary Medical Science, [S. 1.], v.77, n.6, p.701-703, 2015. Available from: $<$ http://doi. org/10.1292/jvms.14-0305>. Accessed: Jun. 15, 2020. doi: 10.1292/jvms.14-0305.

DIENES, L. Morphology and nature of the pleuropneumonia group of organisms. Journal of Bacteriology, [S. 1.], v.50, n.4, p.441-458, 1945.

DRIGGERS, T. Respiratory Diseases, Diagnostics, and Therapy in Snakes. Veterinary Clinics of North America: Exotic Animal Practice, [S. 1.], v.3, n.2, p.519-530, 2000. Available from: $<$ http:// doi.org/10.1016/S1094-9194(17)30086-5>. Accessed: Jun. 15, 2020. doi: 10.1016/S1094-9194(17)30086-5.

FUNK, R. S. Snakes. In: Reptile Medicine and Surgery. [S. 1.]: Elsevier, 2006. p. 675-682. E-book. Available from: <http://doi. org/10.1016/B0-72-169327-X/50042-0>. Accessed: Jun. 3, 2020. Accessed: June 15, 2020. doi: 10.1016/B0-72-169327-X/50042-0.

JACOBSON, E. R. et al. Mycoplasmosis and upper respiratory tract disease of tortoises: A review and update. The Veterinary Journal, [S. 1.], v.201, n.3, p.257-264, 2014. Available from: $<$ http://doi.org/10.1016/j.tvj1.2014.05.039>. Accessed: Jun. 15, 2020. doi: 10.1016/j.tvj1.2014.05.039.

JACOBSON, E. R.; BERRY, K. H. Mycoplasma testudineum in free-ranging Desert Tortoises, Gopherus agassizii. Journal of Wildlife Diseases, [S. 1.], v.48, n.4, p.1063-1068, 2012. Available from: <http://doi.org/10.7589/2011-09-256>. Accessed: Jun. 15, 2020. doi: 10.7589/2011-09-256.

KIMURA, M. A simple method for estimating evolutionary rates of base substitutions through comparative studies of nucleotide sequences. Journal of Molecular Evolution, [S. 1.], v.16, n.2, p.111-120, 1980. Available from: <http://doi.org/10.1007/ BF01731581>. Accessed: Jun. 15, 2020. doi: 10.1007/ BF01731581.

KIRCHHOFF, H. et al. Mycoplasma crocodyli sp. nov., a new species from crocodiles. International Journal of Systematic Bacteriology, [S. 1.], v.47, n.3, p.742-746, 1997. Available from: $<$ http://doi.org/10.1099/00207713-47-3-742>. Accessed: Jun. 15, 2020. doi: $10.1099 / 00207713-47-3-74$

KUMAR, S. et al. MEGA X: Molecular evolutionary genetics Analysis across Computing Platforms. Molecular Biology and Evolution, [S. 1.], v.35, n.6, p.1547-1549, 2018. Available from: $<$ http://doi.org/10.1093/molbev/msy096>. Accessed: Jun. 15, 2020. doi: 10.1093/molbev/msy096. 
LECIS, R. et al. Detection and characterization of Mycoplasma spp. and Salmonella spp. in free-living European Tortoises (Testudo hermanni, Testudo graeca, and Testudo marginata). Journal of Wildlife Diseases, [S. 1.], v.47, n.3, p.717-724, 2011. Available from: <http://doi.org/10.7589/0090-3558-47.3.717>. Accessed: Jun. 15, 2020. doi: 10.7589/0090-3558-47.3.71.

LOVSTAD, J. N. et al. Novel herpesvirus associated with oropharyngeal squamous cell carcinoma in smooth green snakes (Opheodrys vernalis). Veterinary Pathology, [S. 1.], v.56, n.4, p.630-635, 2019. Available from: <http://doi. org/10.1177/0300985819837722>. Accessed: Jun. 15, 2020. doi: $10.1177 / 0300985819837722$.

MARSCHANG, R. E. et al. Detection of a Mycoplasma sp. in a Python (Morelia spilota) with Stomatitis. Journal of Herpetological Medicine and Surgery, [S. 1.], v.26, n.3-4, p.90, 2016. Available from: <http://doi.org/10.5818/1529-9651-26.34.90>. Accessed: Jun. 15, 2020. doi: 10.5818/1529-9651-26.3-4.9.

MEHLER, S. J.; BENNETT, R. A. Upper alimentary Tract Disease. In: Reptile Medicine and Surgery. [S. 1.]: Elsevier 2006. p.924-930. E-book. Available from: < http://doi.org/10.1016/ B0-72-169327-X/50076-6>. Accessed: Jun. 3, 2020. doi: 10.1016/ B0-72-169327-X/50076-6.

NASCIMENTO, E. R.; PEREIRA, V. L. de A. Micoplasmoses. In: FABIO, J.; ROSSINI, L. (org.). Doenças das Aves. 2. ed. Campinas: FACTA, 2009.

OSSIBOFF, R. J. et al. A Mycoplasma species of Emydidae Turtles in the Northeastern USA. Journal of Wildlife Diseases, [S. 1.], v.51, n.2, p.466-470, 2015. Available from: $<$ http://doi.org/10.7589/201404-086>. Accessed: Jun. 15, 2020. doi: 10.7589/2014-04-086.

PENNER, J. D. et al. A novel Mycoplasma sp. associated with proliferative tracheitis and pneumonia in a burmese python (Python molurus bivittatus). Journal of Comparative Pathology, [S. 1.], v.117, n.3, p.283-288, 1997. Available from: <http://doi org/10.1016/S0021-9975(97)80024-2>. Accessed: Jun. 15, 2020. doi: 10.1016/S0021-9975(97)80024-2.
SAMBROOK, J.; RUSSELL, D. W. Purification of nucleic Acids by Extraction with Phenol:Chloroform. Cold Spring Harbor Protocols, [S. 1.], v.2006, n.1, p.pdb.prot4455, 2006. Available from: <http://doi.org/10.1101/pdb.prot4455>. Accessed: Jun. 15, 2020. doi: 10.1101/pdb.prot4455.

SCHMIDT, V. et al. Detection of pathogens in Boidae and Pythonidae with and without respiratory disease. Veterinary Record, [S. 1.], v.172, n.9, p.236-236, 2013. Available from: <http://doi.org/10.1136/ vr.100972>. Accessed: Jun. 15, 2020. doi: 10.1136/vr.100972.

SCHUMACHER, J. Selected Infectious Diseases of Wild Reptiles and Amphibians. Journal of Exotic Pet Medicine, [S. l.], v.15, n.1, p.18-24, 2006. Available from: <http://doi.org/10.1053/j. jepm.2005.11.004>. Accessed: Jun. 15, 2020. doi: 10.1053/j. jepm.2005.11.00.

SEIMON, T. A. et al. Disease screening in southern river terrapins (Batagur affinis edwardmolli) IN CAMBODIA. Journal of Zoo and Wildlife Medicine, [S. 1.], v.48, n.4, p.1242-1246, 2017. Available from: <http://doi.org/10.1638/1042-7260-48.4.1242>. Accessed: Jun. 15, 2020. doi: 10.1638/1042-7260-48.4.124.

STARCK, J. M. et al. Morphology and morphometry of the lung in corn snakes (Pantherophis guttatus) Infected with Three Different Strains of Ferlavirus. Journal of Comparative Pathology, [S. 1.], v.156, n.4, p.419 435, 2017. Available from: <http://doi.org/10.1016/j.jcpa.2017.02.001>. Accessed: Jun. 15, 2020. doi: 10.1016/j.jcpa.2017.02.001.

STENGLEIN, M. D. et al. Ball Python nidovirus: a candidate etiologic agent for severe respiratory disease in Python regius. mBio, [S. 1.], v.5, n.5, p.e01484-14, 2014. Available from: <http:// doi.org/10.1128/mBio.01484-14>. Accessed: Jun. 15, 2020. doi: 10.1128/mBio.01484-14.

UPHOFF, C. C.; DREXLER, H. G. Comparative PCR analysis for detection of mycoplasma infections in continuous cell lines. In Vitro Cellular \& Developmental Biology - Animal, [S. 1.], v.38, n.2, p.79-85, 2002. Available from: <http://doi.org/10.1290/10712690(2002)038<0079:CPAFDO $>2.0$. CO;2>. Accessed: Jun. 15, 2020. doi: 10.1290/1071-2690(2002)038<0079:CPAFDO >2.0.CO;2. 